\title{
Vesicles prepared from Streptococcus mutans demonstrate the presence of a second glucose transport system
}

\author{
Nicole D. Buckley† and lan R. Hamilton
}

Author for correspondence: Ian R. Hamilton. Tel: +1 204789 3615. Fax: +1 2048884113.

Department of Oral Biology, Faculty of Dentistry,

University of Manitoba,

Winnipeg, Canada R3E OW2

\begin{abstract}
Streptococcus mutans, an important aetiological agent of dental caries, is known to transport glucose via the phosphoenolpyruvate (PEP) phosphotransferase system (PTS). An alternative non-PTS glucose transport system in S. mutans Ingbritt was suggested by the increased ATP-dependent phosphorylation of glucose and the presence of higher cellular concentrations of free glucose in cells grown in continuous culture under PTS-repressed conditions compared to those resulting in optimal PTS activity. A method was developed for the preparation of membrane vesicles in order to study this system in the absence of PTS activity. These vesicles had very low activity of the cytoplasmic enzymes, glucokinase, pyruvate kinase and lactate dehydrogenase. This, coupled with the lack of glycolytic activity and the inability to transport glucose, suggested that the vesicles would also be deficient in PTS activity because of the absence of the general soluble PTS proteins, Enzyme I and HPr, required for the transport of all PTS sugars. Freezefracture electron microscopy and membrane $\mathrm{H}^{+}$-ATPase analysis indicated that over $90 \%$ of the vesicles had a right-side-out orientation. Vesicles from cells grown in continuous culture under PTS-dominant and PTS-repressed conditions both exhibited glucose counterflow. This indicates the presence of a constitutive non-PTS carrier in the organism capable of transporting glucose and utilizing ATP for glucose phosphorylation. Analysis of growth yields of cells grown under PTS-repressed and PTS-optimal conditions suggests that ATP, or an equivalent high energy molecule, must be involved in the actual transport process. This analysis is consistent with an ATP-binding protein model such as the Msm transport system reported by R. R. B. Russell and coworkers (J Biol Chem 267, 4631-4637), but it does not exclude the possibility of a separate permease for glucose.
\end{abstract}

Keywords: Streptococcus mutans, glucose transport, PEP phosphotransferase system, membrane vesicles

\section{INTRODUCTION}

Streptococcus mutans is a major aetiological agent of dental caries, catabolizing dietary carbohydrates to acid endproducts that, once excreted, can contribute to the demineralization of the tooth enamel (Hamada \& Slade, 1980; van Houte, 1986). Results of early studies on sugar

†Present address: Department of Microbiology, University of Texas Health Science Center, San Antonio, Texas, USA.

Abbreviations: PEP, phosphoenolpyruvate; PTS, phosphotransferase system. transport by $S$. mutans suggested that the organism possesses at least two distinct systems for glucose uptake (Hamilton, 1984, 1987). The phosphoenolpyruvate (PEP): sugar phosphotransferase system (PTS) (Meadow et al., 1990; Postma et al., 1993) is a principal transport system in oral streptococci for glucose and a variety of sugars, including mannose, fructose, sucrose, lactose and maltose (Vadeboncoeur, 1984). In the PTS, phosphate from PEP is transferred via the general proteins HPr and Enzyme I (EI), through the sugar-specific, membranebound carrier, Enzyme II (EII), onto the incoming carbohydrate. In some cases, the latter phosphoryl transfer requires the participation of a sugar-specific Enzyme III, 
or simply III, often in EII/III pairs (Meadow et al., 1990; Postma et al., 1993).

Early studies with toluene-permeabilized cells of $S$. mutans Ingbritt grown in continuous culture showed that the glucose-PTS was repressed under a variety of conditions including growth at low $\mathrm{pH}$ (Hamilton \& Ellwood, 1978), at high growth rates and with excess glucose (Ellwood et al., 1979), and following transition to growth on sucrose (Ellwood \& Hamilton, 1982). Later studies demonstrated that the synthesis of the membrane-bound EII for glucose $\left(\mathrm{EII}^{\mathrm{glc}}\right)$ and mannose $\left(\mathrm{EII}^{\mathrm{man}}\right)$, but not the general proteins, was affected by environmental factors, particularly the glucose concentration and the $\mathrm{pH}$ of growth (Vadeboncoeur et al., 1987, 1991; Hamilton et al., 1989). Interestingly, the glucose uptake and glycolytic rates were not similarly inhibited, suggesting that during PTS repression $S$. mutans employed an alternative, nonPTS glucose transport system (Hamilton, 1987). An early model of glucose transport linked to proton-motive force in $S$. mutans was proposed by Hamilton \& St Martin (1982), but subsequently questioned by studies using the glucose analogue 6-deoxyglucose (Dashper \& Reynolds, 1990).

In order to examine glucose transport in intact cells, it is necessary to disrupt cellular metabolism and, as a consequence, it is then difficult to discriminate between glucose transport inhibition due to lack of a transporter or interference with an existing system that relies on active metabolism. A novel way to attack the problem is through the use of membrane vesicles. Kaback (1960) first reported that isolated membranes of Escherichia coli strain W could catalyse the uptake of proline. Subsequent studies showed that the membrane preparation contained plasma membrane vesicles devoid of cytoplasmic constituents that behaved as 'osmotically intact structures' retaining many transport functions of whole cells (Kaback, 1968, 1972, 1974). Vesicles of $S$. mutans afford several advantages over: whole cells for the study of carbohydrate transport: (a) the PTS would be inactivated by the removal of the general proteins, $\mathrm{HPr}$ and EI, as well as the enzymes capable of generating PEP, (b) transport substrates would not be metabolized, and (c) the transport system could be studied in isolation without the use of inhibitors or substrate analogues.

In this paper, we provide evidence for an ATP-dependent, non-PTS sugar transport system in $S$. mutans Ingbritt grown in continuous culture under conditions that repress PTS activity. For confirmation of such a non-PTS process, membrane vesicles were prepared with mutanolysin and lysozyme from cells grown under both PTS repressive and non-repressive conditions. Vesicles obtained by this method had a right-side-out orientation and were essentially free of cytoplasmic constituents permitting the study of non-PTS glucose transport in the absence of PTS activity. Glucose counterflow experiments conducted with such vesicles provide evidence for the presence in both cell types of a non-PTS carrier capable of transporting glucose. It is concluded that $S$. mutans possesses two glucose transport systems, the PEP-dependent PTS and a second, constitutive process probably linked to the ATP-dependent phosphorylation of glucose.

\section{METHODS}

Bacterial strain and growth conditions. The $S$. mutans strain Ingbritt used in this study was kindly supplied by J. Sandham, Toronto, Canada. The culture was maintained and assessed for purity as described previously (Hamilton \& Ellwood, 1978). Cultures were grown in chemostats at a dilution rate $(D)$ of $0 \cdot 1 \mathrm{~h}^{-1}$ in semi-defined medium (Hamilton \& Buckley, 1991) under the following conditions: condition $\mathrm{A}(5 \mathrm{mM}$ glucose at $\mathrm{pH} 7 \cdot 0$ ), which results in optimal glucose-PTS activity (PTS-O cells), and condition $\mathrm{B}(50 \mathrm{mM}$ glucose $\mathrm{pH} 5.5)$, which results in repression of the glucose-PTS (PTS-R cells) (Hamilton et al., 1979, 1989; Vadeboncoeur et al., 1987, 1991).

Phosphorylation of glucose by ATP and PEP. Cells of $S$. mutans Ingbritt growing under conditions $A$ and $B$ were harvested from the chemostat overflow over $3-16 \mathrm{~h}$ into a container cooled to $0{ }^{\circ} \mathrm{C}$, centrifuged at $10000 \mathrm{~g}$ for $10 \mathrm{~min}$, washed twice and resuspended at $10 \mathrm{mg}$ (dry wt) $\mathrm{ml}^{-1}$ in $10 \mathrm{mM}$ potassium phosphate buffer $(\mathrm{pH} 7 \cdot 0)$ containing $14 \mathrm{mM} 2$-mercaptoethanol and $5 \mathrm{mM} \mathrm{MgCl}{ }_{2}$. Cells were permeabilized with toluene (Hamilton et al., 1979) and assayed in the following reaction mixture (final concentrations): $50 \mathrm{mM}$ potassium phosphate buffer ( $\mathrm{pH} 7 \cdot 0$ ), $5 \mathrm{mM} \mathrm{MgCl}, 5 \mathrm{mM}$ 2-mercaptoethanol, $10 \mathrm{mM}$ $\mathrm{NaF}, 2 \mathrm{mM}\left[{ }^{14} \mathrm{C}\right]$ glucose $\left(0 \cdot 1 \mathrm{Ci} \mathrm{mol}^{-1}, 3 \cdot 7 \mathrm{GBq} \mathrm{mol}^{-1}\right) 2 \mathrm{mM}$ ATP or PEP and $250 \mu \mathrm{g}$ (dry wt) cells in a $500 \mu \mathrm{l}$ volume. Controls contained no phosphoryl donor. After $15 \mathrm{~min}$ in cubation at $37^{\circ} \mathrm{C}$, the phosphorylated product was precipitated with $30 \mathrm{mM} \mathrm{BaBr}$ in $90 \%$ ethanol, collected on filters and the filters counted in Aquasol (NEN Research Products).

Determination of intracellular glucose and glucose 6-phosphate. Samples of steady-state cultures were rapidly drawn from the chemostat and filtered through $0.2 \mu \mathrm{m}$ Uni-Pore Polycarbonate membrane filters (Bio-Rad) and immediately washed with $10 \mathrm{mM}$ Tris $/ \mathrm{HCl}$ buffer $(\mathrm{pH} 7 \cdot 0)$. The filters were then immersed in $3.0 \mathrm{ml} 0.5 \mathrm{M}$ perchloric acid, incubated at room temperature for $30 \mathrm{~min}$ to extract the cells and then washed in $1.0 \mathrm{ml}$ water. As a control for any residual medium in the filters, equivalent volumes of spent medium were passed through a duplicate set of filters and subjected to perchloric acid extraction. In all cases, the pooled extract and wash was titrated to $\mathrm{pH} 7.5$ with $5 \mathrm{M} \mathrm{K}_{2} \mathrm{CO}_{3}$ following the addition of $100 \mu \mathrm{l}$ $1 \mathrm{mM}$ triethanolamine buffer $(\mathrm{pH} 7.5)$ and then centrifuged at $10000 \mathrm{~g}$ for $10 \mathrm{~min}$ to remove the potassium perchlorate. The supernatant was then filtered through a $0 \cdot 2 \mu \mathrm{m}$ filter and immediately assayed for glucose and glucose 6-phosphate.

Glucose 6-phosphate was analysed by a modification of the glucose-6-phosphate dehydrogenase assay of Bergmeyer (1974). The reaction went to completion within $3 \mathrm{~min}$, at which time known quantities of glucose 6-phosphate were added to samples to serve as internal standards and a second absorbance reading was made. Glucose was assayed with the glucose oxidaseperoxidase coupled reaction of Kingsley \& Getchell (1960). A duplicate set of tubes was included in each assay to which known amounts of glucose were added as an internal standard.

Preparation of membranes, vesicles and crude-cell extract. Membrane fragments of $S$. mutans Ingbritt were prepared with cells harvested from the chemostat overflow (Hamilton \& Buckley, 1991). Vesicles were prepared with a combination of the membrane technique described above and the vesicle preparation procedure of Otto et al. (1984). Steady-state cells were collected from the chemostat, washed twice in cold water 
and resuspended in $40 \mathrm{ml}$ vesicle buffer $[10 \mathrm{mM}$ Tris/HCl (pH 7.5), $10 \mathrm{mM} \mathrm{MgSO}_{4}, 2 \mu \mathrm{M}$ pepstatin and $14 \mathrm{mM}$ mercaptoethanol]. The cell suspension was sonicated for 2 min with a Kontes sonifier (Kontes Scientific Glassware) at a power setting of 4 to disperse the cells before addition to $160 \mathrm{ml}$ prewarmed osmotic buffer $[75 \mathrm{mM}$ Tris/ $\mathrm{HCl}(\mathrm{pH} 7 \cdot 5), 2 \mathrm{mM} \mathrm{MgSO}$, $40 \mathrm{mM}$ amino- $n$-caproic acid, $6 \mathrm{mM} p$-aminobenzamide and $14 \mathrm{mM}$ mercaptoethanol] containing $1.25 \mathrm{~g}$ lysozyme and $7500 \mathrm{U}$ mutanolysin (Sigma). After a $3 \mathrm{~h}$ incubation at $37^{\circ} \mathrm{C}$, the resulting protoplasts were washed and resuspended in $40 \mathrm{ml}$ vesicle buffer, and lysed by the addition of $10.8 \mathrm{ml}$ saturated $\mathrm{K}_{2} \mathrm{SO}_{4}$. The preparation was treated with DNase and RNase (each $10 \mu \mathrm{g} \mathrm{ml}^{-1}$ ) for $15 \mathrm{~min}$ with stirring at $37^{\circ} \mathrm{C}$, after which $9 \cdot 0 \mathrm{ml} 200 \mathrm{mM}$ EDTA was added and the preparation incubated for an additional $15 \mathrm{~min}$. The cell debris, including vesicles, was collected by centrifugation, washed once and resuspended in $60 \mathrm{ml}$ vesicle buffer. The vesicles were purified by discontinuous density gradient centrifugation: $10 \mathrm{ml}$ of the vesicle/membrane suspension was placed gently onto $10 \mathrm{ml} 60 \%(\mathrm{w} / \mathrm{v})$ sucrose overlayed with $15 \mathrm{ml} 20 \%(\mathrm{w} / \mathrm{v})$ sucrose and centrifuged at $67500 \mathrm{~g}$ for $16 \mathrm{~h}$ in a Beckman SW 28 swinging-bucket rotor. The vesicles, collected at the interface between the two layers, were carefully removed, collected by centrifugation at $48000 \mathrm{~g}$ for $30 \mathrm{~min}$, washed once and resuspended in vesicle buffer. The final vesicle pellet was resuspended in buffer, distributed in $200 \mu \mathrm{l}$ aliquots and stored at $-70{ }^{\circ} \mathrm{C}$ until used.

Crude cell extract of $S$. mutans Ingbritt was prepared by a variation of the sonication method described by Khandelwal \& Hamilton (1971). Cells grown in condition B (see above) were collected from the chemostat, washed in vesicle buffer and sonicated for $3 \mathrm{~min}$ at $0{ }^{\circ} \mathrm{C}$ in the presence of $5 \mu \mathrm{m}$ diameter beads (cells-to-beads ratio of $3: 1$ ) in a Branson sonifier (Heat Systems Ultrasonics) followed by centrifugation $(30000 \mathrm{~g}$ for $15 \mathrm{~min})$. The supernatant was then treated with RNase and DNase (each $10 \mu \mathrm{g} \mathrm{ml}^{-1}$ ) for $30 \mathrm{~min}$ and dialysed $(10000 \mathrm{MW}$ exclusion limit) overnight against 41 vesicle buffer with one change of buffer.

Electron microscopy. To characterize the process of vesicle formation, samples were removed at different stages of vesicle preparation and fixed by the addition of $50 \%$ glutaraldehyde directly to the specimen in suspension $(40 \mu l$ fixative per $\mathrm{ml}$ sample). They were post fixed with $1 \%$ osmium tetroxide and embedded in JemBed 812 (JB EM Services) (Yuan \& Gulyas, 1981 ) and the specimens sectioned on an LKB Ultratome EIII with a diamond knife and the silver sections $(50-60 \mathrm{~nm})$ were collected on 300-mesh grids. The sections were stained with uranyl acetate (Stempek \& Ward, 1964) and post-stained with lead citrate (Venable \& Coggeshell, 1965). The sections were viewed with a Philips model 201 electron microscope at an acceleration voltage of $60 \mathrm{keV}$ and images were recorded on Kodak positive reversal film 5302 . The $S$. mutans vesicles were also examined by freeze-fracture electron microscopy to determine their orientation, in the laboratory of T. J. Beveridge, University of Guelph, using the techniques of Chapman \& Staehelin (1986) and Martin \& Beveridge (1986).

Enzyme assays. Vesicles, membranes and crude-cell extract prepared from cells grown under condition B were assayed for the presence of cytoplasmic and membrane-associated enzymes. Vesicles were sonicated for $1 \mathrm{~min}$ at $0{ }^{\circ} \mathrm{C}$ with a Branson sonifier prior to enzyme assays to liberate trapped cytoplasmic contents. Glucokinase was assayed by the method of Porter et al. (1980), while pyruvate kinase was assayed in the presence of the activator glucose 6-phosphate (Yamada \& Carlsson, 1975). Lactate dehydrogenase was assayed in the presence of its activator, fructose 1,6-bisphosphate, and saturating amounts of pyruvate (Brown \& Wittenberger, 1972). The membrane- bound, proton-translocating ATPase $\left(\mathrm{H}^{+}\right.$-ATPase $)$was assayed by the method of Bender $e t$ al. (1986) modified as described by Hamilton \& Buckley (1991). Units are expressed as nmol $P_{\mathbf{i}}(\mathrm{mg}$ protein $)^{-1} \min ^{-1}$.

All enzymes were measured in vesicle and membrane preparations before and after sodium dodecyl sulfate treatment (SDS: protein ratio of 1:1) to solubilize bound protein. The protein content of the membranes, vesicles and crude cell extracts was determined by a modification of the Lowry technique as described by Peterson (1983) using bovine serum albumin as standard.

Measurement of glycolytic activity. Glycolytic activity of the vesicles prepared from cells grown under conditions $A$ and $B$ was assayed as described previously (Hamilton \& St Martin, 1982), except that the vesicles were resuspended at $0.5 \mathrm{mg}$ protein $\mathrm{ml}^{-1}$ in vesicle buffer in a $\mathrm{pH}$-stat at a final volume of $5.0 \mathrm{ml}$.

Glucose counterflow. Counterflow was used to test the ability of vesicles to carry out carrier-mediated facilitated diffusion of glucose. For 'glucose-loading', vesicles were incubated for $1 \mathrm{~h}$ at room temperature with $100 \mathrm{mM}$ glucose in $10 \mathrm{mM}$ Tris $/ \mathrm{HCl}$ buffer ( $\mathrm{pH} 7.5$ ) containing $10 \mathrm{mM} \mathrm{MgSO}, 14 \mathrm{mM}$ mercaptoethanol, $2 \mathrm{mM}$ PMSF and $2 \mu \mathrm{M}$ pepstatin. The vesicles were collected by centrifugation at $48000 \mathrm{~g}$ for $10 \mathrm{~min}$, the supernatant was decanted carefully and any residual fluid in the centrifuge tube removed with cotton swabs. Vesicles were resuspended in $10 \mathrm{ml}$ of the same buffer containing $2 \mathrm{mM}$ $\left[{ }^{14} \mathrm{C}\right]$ glucose (5000 d.p.m. nmol $\left.{ }^{-1}\right)$ and $1 \mathrm{ml} \mathrm{samples}$ were collected periodically by centrifugation through silicone oil $(1: 1$ mixture of Dow Corning fluid 550 and 556, specific gravity $1 \cdot 0182 \pm 0.00027)$ in a microfuge at $15000 \mathrm{~g}$ for $3 \mathrm{~min}$. The radioactivity of the vesicles in the pellet was then measured with Aquasol (NEN Canada) in a scintillation counter. Controls consisted of vesicles incubated without added glucose ('unloaded' vesicles). Counts derived in this process represented the total radioactivity associated with the pellet, including any glucose inside the vesicles and that trapped in the extracellular space. The internal radioactivity was calculated by subtracting the label in the external water volume of the sample from the total radioactivity in the vesicle pellet. The data were expressed as the ratio of the intracellular versus extracellular glucose concentration.

Water volume of whole cells and vesicles. The intracellular and extracellular water content of $S$. mutans Ingbritt cells was determined as previously described (Hamilton \& Buckley, 1991). The total aqueous volume was determined with ${ }^{3} \mathrm{H}_{2} \mathrm{O}$ (2000 d.p.m. per ml final volume), while the extracellular water volume was measured with $\left[{ }^{3} \mathrm{H}\right]$ polyethylene glycol (1500 d.p.m. per $\mathrm{ml}$ final volume). After incubation with the labelled probe for $10 \mathrm{~min}$, the cell pellets were collected by silicone centrifugation as described above and the radioactivity associated with the cells was measured. The intracellular water volume for $S$. mutans Ingbritt under the experimental conditions employed was $2.49 \pm 0.06 \mu \mathrm{l}(\mathrm{mg} \text { dry wt })^{-1}$ at $\mathrm{pH} 7.0$ and $2.52 \pm 0.05 \mu \mathrm{l}(\mathrm{mg} \mathrm{dry} \mathrm{wt})^{-1}$ at $\mathrm{pH} 5.5$, while the extracellular volumes were $0.33 \pm 0.03$ and $0.36 \pm 0.02 \mu \mathrm{l}(\mathrm{mg} \mathrm{dry} \mathrm{wt})^{-1}$, respectively (means $\pm \mathrm{SE} ; n=6$ ).

The internal and external water volumes of the vesicles were determined as described above for whole cells, except that the suspensions were in vesicle buffer and centrifugation was through a $65: 35(\mathrm{v} / \mathrm{v})$ silicone oil mixture of Dow Corning fluids 556 and 550 (specific gravity $0 \cdot 9877 \pm 0 \cdot 00032$ ), respectively. The internal vesicle water volume was $4.46 \pm 1.50 \mu \mathrm{l}(\mathrm{mg}$ protein $)^{-1}$ and the external vesicle water volume was 4.98 $\pm 2 \cdot 06 \mu \mathrm{l}(\mathrm{mg} \text { protein })^{-1}$. 
Table 1. PEP- and ATP-dependent phosphorylation of glucose by permeabilized cells of $S$. mutans Ingbritt

Cells were grown in continuous culture at a dilution rate of $0 \cdot 1 \mathrm{~h}^{-1}$ under conditions resulting in optimal (P'TS-O) and repressed (PTS-R) PTS activity.

\begin{tabular}{|c|c|c|c|c|c|c|}
\hline \multirow[t]{3}{*}{ Cells } & \multirow{3}{*}{$\begin{array}{l}\text { Glucose } \\
\text { concn } \\
(\mathrm{mM})\end{array}$} & \multirow{3}{*}{$\begin{array}{c}\text { Growth } \\
\text { pH }\end{array}$} & \multirow{3}{*}{$\begin{array}{c}\text { EIIgle } \\
\text { activity* }\end{array}$} & \multicolumn{2}{|c|}{ Phosphorylation $\dagger$} & \multirow{3}{*}{$\begin{array}{l}\text { Ratio } \\
\text { PEP/ } \\
\text { ATP } \ddagger\end{array}$} \\
\hline & & & & \multicolumn{2}{|c|}{ Phosphoryl donor: } & \\
\hline & & & & PEP & ATP & \\
\hline PTS-O & 5 & $7 \cdot 0$ & $319 \$$ & $74 \cdot 4 \pm 5 \cdot 3$ & $16 \cdot 4 \pm 2 \cdot 3$ & $4 \cdot 54$ \\
\hline PTS-R & 50 & $5 \cdot 5$ & $4 \|$ & $6.9 \pm 0.8$ & $20 \cdot 7 \pm 3 \cdot 1$ & 0.33 \\
\hline
\end{tabular}

${ }^{*} \mathrm{nmol}(\mathrm{mg} \text { membrane protein })^{-1} \mathrm{~min}^{-1}$ in the presence of excess $\mathrm{HPr}$, EI and III.

† nmol (mg dry wt cells) ${ }^{-1} \mathrm{~min}^{-1}$.

$\ddagger$ Differences between PEP and ATP as substrates statistically significant at the $95 \%$ level.

$\$$ Adapted from Vadeboncoeur et al. (1989).

$\|$ From Vadeboncoeur et al. (1987).

Table 2. Intracellular glucose and glucose 6-phosphate of S. mutans Ingbritt

Cells were grown in continuous culture at a dilution rate of $0.1 \mathrm{~h}^{-1}$ under conditions resulting in optimal (PTS-O) and repressed (P'TS-R) PTS activity.

\begin{tabular}{|c|c|c|c|c|c|c|c|}
\hline \multirow[t]{2}{*}{ Cells } & \multirow{2}{*}{$\begin{array}{c}\text { Medium } \\
\text { glucose } \\
\text { concn } \\
(\mathrm{mM})\end{array}$} & \multirow[t]{2}{*}{$\begin{array}{c}\text { Growth } \\
\mathrm{pH}\end{array}$} & \multicolumn{2}{|c|}{$\begin{array}{l}\text { Intracellular concn } \\
\qquad(\mu \mathrm{M})\end{array}$} & \multirow[t]{2}{*}{$\begin{array}{l}\text { Ratio } \\
\text { G/G6P }\end{array}$} & \multirow{2}{*}{$\begin{array}{c}\text { Actual } \\
\text { culture } \\
\text { glucose } \\
(\mu \mathrm{M})\end{array}$} & \multirow[t]{2}{*}{$\begin{array}{l}\text { Ratio } \\
G_{\text {in }} / G_{\text {out }}\end{array}$} \\
\hline & & & G* & G6P* & & & \\
\hline PTS-O & 5 & $7 \cdot 0$ & $969 \pm 125$ & $836 \pm 113$ & $1 \cdot 2$ & $3 \pm 1$ & 323 \\
\hline PTS-R & 50 & $5 \cdot 5$ & $1356 \pm 128$ & $264 \pm 95$ & $5 \cdot 1$ & $210 \pm 90$ & 6.5 \\
\hline
\end{tabular}

* G, glucose; G6P, glucose 6-phosphate. Comparative values between the PTS-O and PTS-R cells are statistically significant at the $95 \%$ level.

Chemicals. Radioactive glucose was purchased from ICN Radiochemicals. Amino- $n$-caproic acid, $p$-aminobenzamide, mercaptoethanol, lysozyme, mutanolysin, and the enzyme assay reagents were purchased from Sigma. All other reagents were of analytical grade.

\section{RESULTS}

\section{Phosphorylation of glucose by ATP and PEP}

Previous research indicated that repression of the glucosePTS in $S$. mutans Ingbritt was associated with an increase in glucokinase activity (Hamilton, 1984). Consequently, a non-PTS system might be a carrier-mediated activetransport process with the incoming glucose molecule phosphorylated internally by glucokinase and ATP. Thus, phosphorylation of glucose by PEP would be a measure of PTS activity, while ATP-dependent phosphorylation could reflect a non-PTS transport system that generates free intracellular glucose that can be phosphorylated by glucokinase. To test for this, PEP and ATP-dependent phosphorylation of $\left[{ }^{14} \mathrm{C}\right]$ glucose was measured with permeabilized cells of $S$. mutans Ingbritt grown in continuous culture $\left(D=0 \cdot 1 \mathrm{~h}^{-1}\right)$ under conditions op- timal for the PTS (5 mM glucose, pH 7.0) (PTS-O cells) and those repressing PTS activity $(50 \mathrm{mM}$ glucose, pH 5.5) (PTS-R cells).

As shown in Table 1, PEP-dependent phosphorylation of glucose by PTS-O cells was almost fivefold higher than that by ATP, confirming that the glucose-PTS is the primary mode of glucose transport in these cells. On the other hand, PTS-R cells growing with higher glucose and at a lower $\mathrm{pH}$ in condition $\mathrm{B}$ exhibited a $90 \%$ decrease in PEP phosphorylation and a $20 \%$ increase in ATP phosphorylation. This change, indicated by the decrease in the PEP/ATP ratio from 4.54 to 0.33 , indicates the increased importance of ATP in glucose phosphorylation as the glucose-PTS is repressed. These results support previous suggestions (Hamilton, 1984, 1987) that at least two distinct glucose uptake systems are present in $S$. mutans Ingbritt: one is the PTS and the second involves the intracellular phosphorylation of glucose by ATP.

This hypothesis was tested by analysing the intracellular steady-state levels of glucose and glucose 6-phosphate during growth in continuous culture under the two conditions. The glucose-PTS would result in the ap- 


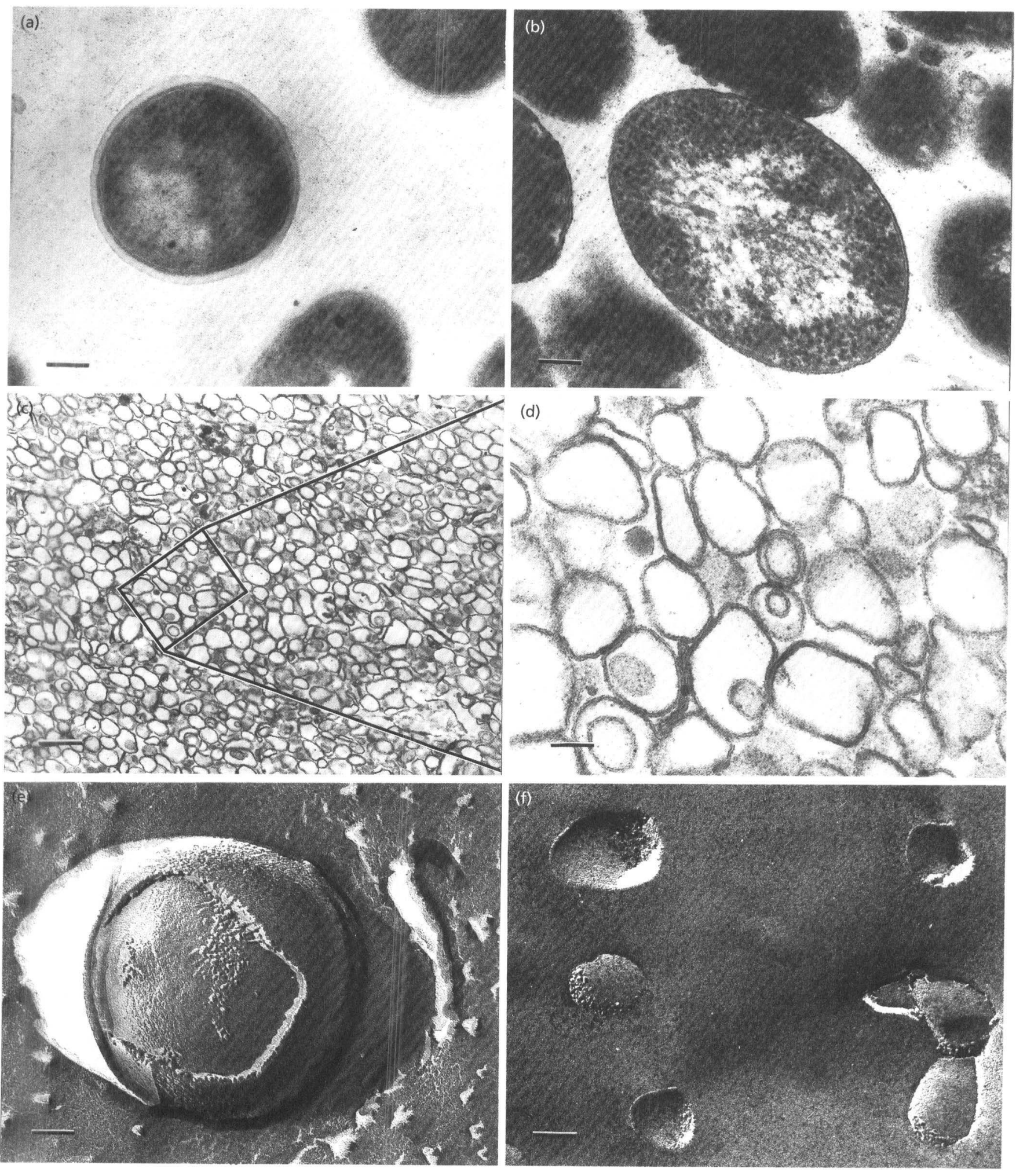

Fig. 1. Electron micrographs of $S$. mutans Ingbritt. (a-d) Negative stain, (e-f) freeze-fracture. (a) Intact cells, (b) protoplasts, (c) vesicles, (d) vesicles at higher magnification, (e) intact cell, (f) vesicles. Bars, $0.1 \mu \mathrm{m}(a, b, d, e, f), 0.5 \mu \mathrm{m}(c)$.

pearance of glucose 6-phosphate in the cell, while nonPTS glucose transport would generate free intracellular glucose. As seen in Table 2, PTS-R cells possessed significantly higher free intracellular glucose than PTS-O cells. This supports the contention that the non-PTS system results in the accumulation of free intracellular 


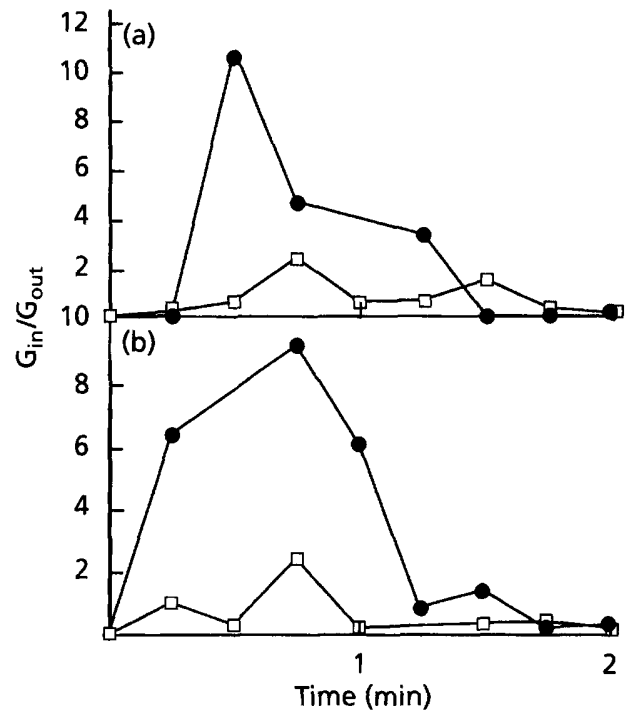

Fig. 2. Glucose counterflow by vesicles of Streptococcus mutans Ingbritt grown under (a) PTS-optimal (PTS-O) and (b) PTSrepressed (PTS-R) conditions in continuous culture. O, Glucoseloaded vesicles; $\square$, glucose-unloaded vesicles.

glucose. The intracellular glucose 6-phosphate concentration in the PTS-R cells was also lower, giving a glucose/glucose 6-phosphate ratio fourfold higher than the PTS-O cells. An analysis of the actual glucose concentration in the chemostat culture fluid, as opposed to the incoming medium, indicated that the PTS-O culture was glucose limited $(3 \mu \mathrm{M})$, while the PTS-R culture contained a very low level of glucose $(210 \mu \mathrm{M})$. The ratio of the intracellular to extracellular glucose $\left(G_{\text {in }} / G_{\text {out }}\right)$ was 323 and 6.5 , respectively, in the PTS-O and PTS-R cultures.

\section{Vesicles of S. mutans Ingbritt}

In order to study the non-PTS transport in the absence of PTS transport activity, vesicles of $S$. mutans Ingbritt were prepared by mutanolysin/lysozyme treatment and potassium sulfate lysis. Electron microscopy was used to evaluate the purity and orientation of the vesicle preparations. Mutanolysin/lysozyme treatment completely removed the cell wall and the cytoplasmic contents were clearly visible, indicating protoplast formation (Fig. 1b). The vesicles obtained following potassium sulfate lysis were intact and of high quality, as evidenced by the lack of contaminating cytoplasmic debris (Fig. 1c, d).

Freeze-fracture of $S$. mutans Ingbritt whole cells (Fig. 1e) resulted in the removal of the cell wall and outer layer of the membrane, revealing the hydrophobic, intramembranous region with clustered particles. Other whole-cell preparations had intramembranous particles at the midline along the poles exposed in dividing cells (data not shown). More than $90 \%$ of vesicles examined by this technique had the same orientation as the whole cells as identified by the aggregation of particles on the inner surface of the membrane (Fig. 1f).
Table 3. Activity of the cytoplasmic enzymes glucokinase, pyruvate kinase and lactate dehydrogenase in vesicles of $S$. mutans Ingbritt compared with that in cell-free extract and membrane preparations

Activities are given as nmol product formed (mg protein $)^{-1}$ $\mathrm{min}^{-1}$. ND, Not detected.

\begin{tabular}{|c|c|c|c|}
\hline Sample & Glucokinase & $\begin{array}{l}\text { Pyruvate } \\
\text { kinase }\end{array}$ & $\begin{array}{c}\text { Lactate } \\
\text { dehydrogenase }\end{array}$ \\
\hline Cell-free extract & $269 \pm 20$ & $75 \pm 3$ & $185 \pm 16$ \\
\hline Vesicles & $14 \pm 3$ & $9 \pm 1$ & $13 \pm 5$ \\
\hline Membrane fraction & ND & 12 & 7 \\
\hline
\end{tabular}

\section{Biochemical properties of vesicles}

Cytoplasmic contamination of the vesicles was evaluated by comparing the levels of glucokinase, pyruvate kinase and lactate dehydrogenase in membranes, vesicles and crude-cell extracts (Table 3 ). The activity of the three enzymes in vesicles relative to that in crude-cell extracts was only $0.05,0.12$ and 0.07 , respectively, and represented activity typical of membrane preparations from the same cells. Thus, potassium sulfate lysis rendered the vesicles essentially free of cytoplasmic enzymes, a fact confirmed by the lack of glycolytic activity by vesicles incubated with glucose in a pH-stat (data not shown).

The sidedness of the vesicles was tested by assaying for $\mathrm{H}^{+}$-ATPase, a membrane-bound enzyme whose catalytic portion faces the cytoplasm in intact cells (Futai \& Kanazawa, 1983). Right-side-out vesicles will not display enzyme activity since ATP cannot traverse the membrane, whereas activity will be detected with inside-out vesicles since the catalytic portion of the $\mathrm{H}^{+}$-ATPase will be exposed to the exterior. Normal intact vesicles possessed no $\mathrm{H}^{+}$-ATPase activity, indicating that they were of the same orientation as whole cells. As a control, vesicles were disrupted by treatment with SDS (SDS:protein ratio $1: 1)$ and again assayed for $\mathrm{H}^{+}$-ATPase activity. Significant $\mathrm{H}^{+}$-ATPase activity $[21.7 \mathrm{nmol}$ phosphate $(\mathrm{mg}$ protein $)^{-1} \mathrm{~min}^{-1}$ ] was detected, indicating that the SDS treatment resulted in exposure of the catalytic portion of the $\mathrm{H}^{+}$-ATPase to ATP and confirming the right-side-out nature of the vesicles. Furthermore, $\mathrm{H}^{+}$-ATPase activity in membranes similarly treated with SDS was reduced fourfold, from $45.5 \mathrm{nmol}$ phosphate released $\mathrm{min}^{-1}(\mathrm{mg}$ protein) ${ }^{-1}$ to $11.6 \mathrm{nmol}$ phosphate released $\mathrm{min}^{-1}$ (mg protein $)^{-1}$, indicating that the vesicles contained significant activity.

\section{Counterflow}

Counterflow experiments were performed on vesicles prepared from cells of $S$. mutans Ingbritt grown under conditions A and B to test for the presence of a glucose carrier. Counterflow predicts that when the vesicles are loaded with unlabelled glucose and then exposed to labelled glucose, entry through a glucose-specific carrier 
will be unaltered, but its exit will be inhibited as it competes with unlabelled substrate for the carrier inside the cell. Thus, if a carrier is present in the vesicle membrane, transient accumulation of glucose will be observed, whereas glucose will not accumulate in the absence of a transport carrier, i.e. simple diffusion. As seen in Fig. 2(a) 'glucose-loaded' vesicles of S. mutans Ingbritt prepared from PTS-R cells showed transient glucose accumulation, while no accumulation was observed with 'unloaded' vesicles, demonstrating the presence of a carrier capable of transporting glucose. Similar results were obtained with five different vesicle preparations and the accumulation was independent of $\mathrm{pH}$. Interestingly, 'glucose-loaded' vesicles prepared from PTS-O cells containing high PTS activity also demonstrated counterflow (Fig. 2b).

\section{DISCUSSION}

The method devised for vesicle preparation with $S$. mutans Ingbritt reported here, as with other vesicle methods (Kaback, 1972), consisted of two stages: protoplast formation followed by lysis and re-formation of the membrane as vesicles. However, unlike previous reports (Eisenberg \& Lillmars, 1975; Chassey \& Giuffrida, 1980; Siegel et al., 1981; Schöller et al., 1983), protoplasts generated by lysozyme and mutanolysin in our system showed little lysis in the absence of osmotic stabilizers. Goodman et al. (1981) reported that significant cell wall loss could occur without acquisition of osmotic sensitivity by protoplasts of $S$. mutans and suggested that strategic cell wall remnants could protect the cell. Nevertheless, electron micrographs of our preparations generated without osmotic stabilization (Fig. 1b) indicated complete loss of cell wall material after mutanolysin and lysozyme treatment, and the vesicles obtained after potassium sulfate lysis of the protoplasts and sucrose density gradient centrifugation were homogeneous, with little contaminating membrane debris.

The vesicles obtained were suitable for transport carrier studies in that they were intact, and possessed the same membrane sidedness as whole cells as shown by freezefracture electron microscopy (Fig. 1e) and the absence of the membrane $\mathrm{H}^{+}$-ATPase activity. Furthermore, the vesicles were essentially devoid of the cytoplasmic enzymes glucokinase, pyruvate kinase and lactate dehydrogenase (Table 3), and therefore would lack the soluble, general PTS proteins, EI and $\mathrm{HPr}$, required for the transport of all PTS sugars. As expected, the vesicles exhibited no glycolytic activity, and therefore would be unable to generate ATP and PEP to support active transport even from endogenous energy reserves. This is supported by the observation that unloaded cells in the counterflow experiment did not take up labelled glucose (Fig. 2).

The surprising feature of the counterflow experiment was the transient accumulation of labelled glucose by the glucose-loaded vesicles of $S$. mutans Ingbritt grown under both the PTS optimal conditions and the PTS repressed conditions. Transient accumulation indicates the presence of a carrier that can recognize glucose and since this occurred with vesicles from both cell types, it is apparent that the carrier is constitutive. It could be argued that counterflow was due to an uncoupled EII ${ }^{\text {glc }}$ of the PTS. This is unlikely for several reasons. Studies with mutants of Salmonella typhimurium defective in HPr and EI lost all ability to grow on PTS sugars unless they possessed alternative non-PTS mechanisms of transport (Postma \& Stock, 1980). In addition, other mutants of E. coli and $S$. typhimurium have been reported that contain EII enzymes able to mediate the facilitated diffusion of substrates, but in all cases, the mutations occur in the genes coding for the EII (Ruijter et al., 1992). Robillard (1987) carried out extensive studies on wild-type EII for mannitol in E. coli both in vesicles and proteoliposomes. These workers have reported that some facilitated diffusion can be observed, but at rates too low to sustain the organisms. Finally, $S$. mutans Ingbritt regulates the glucose-PTS at the genetic level through repression ( 80 -fold) of the EII enzyme under growth conditions similar to those used in this study (Hamilton et al., 1989; Vadeboncoeur et al., 1987; Table 1). Thus, it appears highly unlikely that the carrier mediating transport is a membrane-associated EII enzyme. Whether the carrier is specific for glucose alone remains to be determined.

Dashper \& Reynolds (1990) have proposed that simple or passive diffusion accounts for non-PTS glucose transport in de-energized cells of $S$. mutans. On teleological grounds, relevant carbohydrate transport by passive diffusion in bacteria is questionable. As stated by Saier (1985), 'as transmembrane permeation represents the first step in the catabolism of exogenous sugars, one would expect the process to be subject to stringent regulatory control'. This would exclude carbohydrate transport by simple diffusion, since the only regulation of such transport would be through induction and repression of pore expression. Saccharolytic oral bacteria are exposed to large, rapid carbohydrate fluxes in the oral cavity (Carlsson, 1986) and it is difficult to envisage how this process would allow for the stringent control suggested by Saier. Experimentally, it has been recognized that passive diffusion of carbohydrates is not a relevant physiological event (Roseman, 1969; Kaback, 1972; Postma \& Stock, 1980; Saier, 1985; Robillard, 1987), with the exception of the glycerol permease which mediates pore-type diffusion in several bacteria, but not streptococci (Saier, 1985). In addition, simple diffusion does not display counterflow, and therefore would not account for the results obtained in this study.

Based on previous data (Hamilton, 1987), a non-PTS glucose carrier in the membrane of $S$. mutans cells would function at high glucose concentrations, at low $\mathrm{pH}$ and at high growth rates, i.e. conditions of glucose-PTS repression. Such a carrier might function to allow facilitated diffusion of glucose into the cell, particularly at high exogenous glucose levels, without any cost to the cell. Indeed, Russell (1990) has reported the presence of a glucose permease in $S$. bovis, the level of which was directly proportional to the external sugar concentration with saturation at $3.6 \mathrm{mM}$ glucose. Facilitated diffusion 
Table 4. Observed and predicted growth yields of $S$. mutans Ingbritt growing in continuous culture at dilution rates from 0.05 to $0.4 \mathrm{~h}^{-1}(\mathrm{pH} 6.5)$ with limiting and excess glucose

Adapted from Hamilton et al. (1978) (Table 1).

\begin{tabular}{|llccc|}
\hline $\begin{array}{l}\text { Medium } \\
\text { glucose }\end{array}$ & $\begin{array}{c}\text { Predominant } \\
\text { metabolism }\end{array}$ & $\begin{array}{c}\text { Observed } \\
\text { yield* }\end{array}$ & $\begin{array}{c}\text { Predicted } \\
\text { yield* }\end{array}$ & $\begin{array}{c}\text { Observed } \\
\text { ATP } \\
\text { yield } \dagger\end{array}$ \\
\hline Limiting & Heterofermentation & $\begin{array}{r}32 \cdot 8 \pm 3.2 \\
9 \cdot 7 \pm 2 \cdot 2\end{array}$ & 31.5 & 3.12 \\
Excess & Homofermentation & 10.5 & 0.92 \\
\hline
\end{tabular}

$*$ Yield $=g$ dry wt cells (mol glucose $)^{-1}$.

$\dagger$ Yield $=$ mol ATP $(\text { mol glucose })^{-1}$ (assuming $10.5 \mathrm{~g}$ cell wt per mol ATP).

would appear not to account for the results with intact cells of $S$. mutans Ingbritt since the glucose concentration gradient across the membrane during growth $\left(G_{\text {in }} / G_{\text {out }}\right.$ 323 to 6.5 ; Table 2) indicates the requirement for active transport.

The existence of a non-PTS glucose transport system in the oral streptococci is supported by recent results showing glucose uptake in strains with altered PTS activity. In our laboratory a mutant of $S$. mutans BM-71 was generated possessing a truncated Enzyme I, lacking 150 amino acids at the C-terminal end. The EI in this strain cannot be phosphorylated by ${ }^{32} \mathrm{PEP}$ and yet can metabolize glucose (unpublished results). A similar observation has been made with an EI-deficient mutant of $S$. salivarius (C. Vadeboncoeur, personal communication).

Facilitated diffusion is usually seen with 'uncoupled' active transporters, that is, active transporters in deenergized cells, such as the lac permease that mediates the active transport of lactose in association with proton motive force (Maloney et al., 1975). In the absence of an electrochemical gradient, the permease mediates the equilibration of the sugar across the membrane. The counterflow detected in cells of $S$. mutans Ingbritt (Fig. 2) could reflect the presence of an 'uncoupled' active transporter. The original model of non-PTS glucose transport in $S$. mutans was a proton-motive force coupled process that was based on the sensitivity of glucose transport to agents known to perturb the proton electrochemical gradients (Hamilton \& St Martin, 1982). Experiments performed by Dashper \& Reynolds (1990), and confirmed by us (unpublished results), appeared to negate this possibility by demonstrating no uptake of the glucose analogue 6-deoxyglucose in response to applied proton and electrical gradients. In addition, the transmembrane gradients of $S$. mutans during growth under conditions typical of dental plaque are probably too low to sustain active transport of glucose (Hamilton, 1990), although leucine transport appears to be linked to protonmotive force (Dashper \& Reynolds, 1993).

Some form of high-energy phosphate-bond linked transport process may function as the non-PTS glucose transport in $S$. mutans. Examples of this type of transport include the $\mathrm{Na}^{+}$-ATPase of Enterococcus faecalis, which accumulates $\mathrm{Na}^{+}$in the cell at the expense of ATP (Kobayashi et al., 1978), and transporters for various amino acids in E. faecalis and Lactococcus cremoris mediating the uptake of L-glutamate, L-aspartate and L-asparagine (Konings et al., 1987). It has also been suggested that in $S$. mutans, glucose uptake could occur via the bindingprotein-dependent sugar uptake system recently reported by Russell et al. (1992). This multiple sugar system (Msm) is encoded on a $12 \mathrm{~kb}$ multi-gene region of the $S$. mutans chromosome and is primarily responsible for the transport of raffinose, melibiose and isomaltosaccharides. One essential gene in this operon is $m s m K$, which codes for an ATP-binding protein, the first such protein identified in Gram-positive bacteria. A recent report (Tao et al., 1993) indicated that unlabelled glucose could effectively disrupt transport of radiolabelled melibiose by $S$. mutans, suggesting the possibility of glucose transport by the $\mathrm{Msm}$ system.

Whether the transport carrier observed in this study is a component of the $\mathrm{Msm}$ system or a separate glucosespecific system is unknown and certainly warrants further investigation. Glucose transport via both systems would require intracellular phosphorylation of glucose by glucokinase and ATP or an equivalent process. Glucokinase is a constitutive enzyme in $S$. mutans Ingbritt; however, its activity is modulated in an inverse relationship with the glucose-PTS (Hamilton, 1984). This is confirmed by the increase in the ATP-dependent phosphorylation of glucose under PTS-repressed conditions (Table 1). Thus, despite variations in growth conditions, the cells are capable of the intracellular conversion of glucose to intermediates of the glycolytic pathway.

What is more problematic is the nature of the transport process itself. Analysis of growth yields of cells grown under PTS-repressed and PTS-optimal conditions suggests that ATP or an equivalent high-energy molecule must be involved in the transport process. This analysis compares the yield coefficients [ $\mathrm{g}$ (dry wt cells) mol glucose $^{-1}$ ] for cells of $S$. mutans Ingbritt grown anaerobically in continuous culture under conditions where the glucose-PTS dominates (limiting glucose) and where the PTS is repressed (excess glucose) (Hamilton, 1987). Since S. mutans is hetero- and homofermentative with limiting 
and excess glucose, respectively (Carlsson \& Griffith, 1974), cell yields can reflect ATP yields, with a value of $10.5 \mathrm{~g}$ bacteria (mol ATP) ${ }^{-1}$ generally being accepted for most bacteria regardless of the substrate source (Gottschalk, 1978). As shown in Table 4 with data generated in a previous chemostat study with $S$. mutans Ingbritt (Hamilton et al., 1979), PTS-dominant cells yielded $32.8 \mathrm{~g}$ dry wt cells (mol glucose) ${ }^{-1}$ or $3 \mathrm{~mol} \mathrm{ATP}$

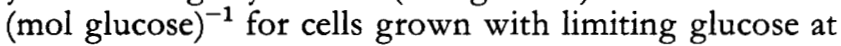
dilution rates 0.05 to 0.4 at $\mathrm{pH} 6.5$. This is consistent with the expected ATP yield from cells utilizing the PTS sugar transport system and recovering an extra ATP during acetate formation via acetyl kinase. On the other hand, PTS-repressed cells, grown with excess glucose under the same conditions, yielded $9.7 \mathrm{~g}$ (mol glucose $)^{-1}$ or $1 \mathrm{~mol}$ ATP (mol glucose $)^{-1}$. This would be in agreement with a phosphate-bond-driven transport in which one ATP is used to bring glucose into the cell and lactate is the sole acid end-product. This analysis is consistent with an ATPbinding protein model such as the $M s m$ system, but it does not exclude the possibility of a separate permease for glucose.

From the ecological perspective of $S$. mutans in dental plaque, the PTS would function as the high-affinity system most of the time since normal plaque has a very low carbohydrate content. However, with frequent dietary sugar consumption, which promotes the formation of dental caries, the combination of the high sugar concentration and the resultant low $\mathrm{pH}$ would favour the proposed phosphate-bond-driven transport system. Thus, this system would be the dominant glucose transport system under conditions promoting the pathogenicity of $S$. mutans in dental plaque.

\section{ACKNOWLEDGEMENTS}

This work was supported by the Medical Research Council of Canada Grant MT-3546 to I.R.H. During a portion of this research, N.D.B. was the recipient of a Manitoba Health Research Council Studentship. We thank Dr T. J. Beveridge, University of Guelph, for his valuable assistance with respect to the electron microscopy of our preparations and Elke Stanik for her assistance with vesicle counterflow experiments.

\section{REFERENCES}

Bender, G. R., Sutton, S. V. W. \& Marquis, R. E. (1986). Acid tolerance, proton permeabilities and membrane ATPases of oral streptococci. Infect Immun 53, 331-338.

Bergmeyer, H. U. (1974). Methods of Enzyme Analysis. Deerfield Beach, Florida: Verlag Chemie International.

Brown, A. T. \& Wittenberger, C. L. (1972). Fructose-1,6diphosphate-dependent lactate dehydrogenase from a cariogenic streptococcus: purification and regulatory properties. $J$ Bacteriol 110, 604-615.

Carlsson, J. (1986). Metabolic activities of oral bacteria. In Textbook of Cariology, pp. 74-106. Edited by A. Thylstrup \& O. Fejerskov. Copenhagen: Munksgaard.

Carlsson, J. \& Griffith, C. J. (1974). Fermentation products and bacterial yields in glucose-limited and nitrogen-limited cultures of streptococci. Arch Oral Biol 19, 1105-1109.
Chapman, R. L. \& Staehelin, L. A. (1986). Freeze-fracture (-etch) electron microscopy. In Ultrastructure Techniques for Microorganisms, pp. 213-240. Edited by H. C. Aldrich \& W. J. Todd. New York: Plenum Press.

Chassey, B. \& Giuffrida, A. (1980). Method for the lysis of Grampositive, asporogenous bacteria with lysozyme. Appl Environ Microbiol 39, 153-158.

Dashper, S. G. \& Reynolds, E. C. (1990). Characterization of transmembrane movement of glucose and glucose analogues in Streptococcus mutans Ingbritt. J Bacteriol 172, 556-563.

Dashper, S. G. \& Reynolds, E. C. (1993). Branched-chain amino acid transport in Streptococcus mutans Ingbritt. Oral Microbiol Immunol 8, 167-171.

Eisenberg, R. J. \& Lillmars, K. (1975). A method for the gentle lysis of Streptococcus sanguis and Streptococcus mutans. Biocbem Biophys Res Commun 65, 378-384.

Ellwood, D. C. \& Hamilton, I. R. (1982). Properties of Streptococcus mutans Ingbritt growing in limiting sucrose in a chemostat: repression of the phosphoenolpyruvate phosphotransferase transport system. Infect Immun 36, 576-581.

Ellwood, D. C., Phipps, P. J. \& Hamilton, I. R. (1979). Effect of growth rate and glucose concentration on the activity of the phosphoenolpyruvate phosphotransferase system in Streptococcus mutans Ingbritt grown in continuous culture. Infect Immun 23, 224-231.

Futai, M. \& Kanazawa, H. (1983). Structure and function of the proton-translocating adenosine triphosphatase $\left(\mathrm{F}_{0} \mathrm{~F}_{1}\right)$ : biochemical and molecular biological approaches. Microbiol Rev 47, 285-312.

Goodman, H., Pollack, J. J., lacono, V. J., Wong, W. \& Shockman, G. (1981). Peptidoglycan loss during hen egg white lysozymeinorganic salt lysis of Streptococcus mutans. J Bacteriol 146, 755-763.

Gottschalk, G. (1978). Bacterial Metabolism. New York: SpringerVerlag.

Hamada, S. \& Slade, H. D. (1980). Biology, immunology and cariogenicity of Streptococcus mutans. Microbiol Rev 44, 331-284.

Hamilton, I. R. (1984). Growth of the oral 'pathogen', Streptococcus mutans, in continuous culture reveals two glucose transport systems. In Continuous Culture 8: Biotechnology, Medicine and the Environment, pp. 58-71. Edited by A. C. R. Dean, D. C. Ellwood \& C. G. T. Evans. Chichester: Ellis Horwood.

Hamilton, I. R. (1987). Effect of changing environment on sugar transport and metabolism by oral bacteria. In Sugar Transport and Metabolism by Gram-Positive Bacteria, pp. 94-133. Edited by J. Reizer \& A. Peterkofsky. Chichester: Ellis Horwood.

Hamilton, I. R. (1990). Maintenance of protonmotive force by Streptococcus mutans and Streptococcus sobrinus during growth in continuous culture. Oral Microbiol Immunol 5, 280-287.

Hamilton, I. R. \& Buckley, N. D. (1991). Adaptation of Streptococcus mutans to acid tolerance. Oral Microbiol Immunol 6, 65-71.

Hamilton, I. R. \& Ellwood, D. C. (1978). Effects of fluoride on carbohydrate metabolism by washed cells of Streptococcus mutans grown at various $\mathrm{pH}$ values in a chemostat. Infect Immun 19, 434-442.

Hamilton, I. R. \& St Martin, E. J. (1982). Evidence for the involvement of protonmotive force in the transport of glucose by a mutant of Streptococcus mutans strain DR0001 defective in the glucose phosphoenolpyruvate phosphotransferase system. Infect Immun 36, 567-575.

Hamilton, I. R., Phipps, P. J. \& Ellwood, D. C. (1979). Effect of growth rate and glucose concentration on the biochemical properties of Streptococcus mutans Ingbritt in continuous culture. Infect Immun 26, 861-869. 
Hamilton, I. R., Gauthier, L., Desjardins, B. \& Vadeboncoeur, C. (1989). Concentration-dependent repression of the soluble and membrane components of the phosphoenolpyruvate:sugar phosphotransferase system of Streptococcus mutans by glucose. J Bacteriol 171, 2942-2948.

van Houte, J. (1986). Bacterial specificity in the etiology of caries. Int Dent J 30, 305-326.

Kaback, H. R. (1960). Uptake of amino acids by 'ghosts' of mutant strains of E. coli. Fed Proc 19, 130.

Kaback, H. R. (1968). The role of the phosphoenolpyruvatephosphotransferase system in the transport of sugars by isolated membrane preparations of Eschericbia coli. J Biol Chem 243, 3711-3724.

Kaback, H. R. (1972). Transport across isolated bacterial cytoplasmic membranes. Biochim Biophys Acta 265, 367-416.

Kaback, H. R. (1974). Transport studies in bacterial membrane vesicles. Science 186, 882-892.

Khandelwal, R. J. \& Hamilton, I. R. (1971). Purification and properties of adenyl cyclase from Streptococcus salivarius. J Biol Chem 246, 3297-3304.

Kingsley, G. R. \& Getchell, G. (1960). Direct ultra micro glucose oxidase method for the determination of glucose in biological fluids. Clin Chem 6, 466-475.

Kobayashi, H., Van Brunt, J. \& Harold, F. M. (1978). ATP-linked calcium transport in cells and membrane vesicles of Streptococcus faecalis. J Biol Chem 253, 2085-2092.

Konings, W. N., de Vrij, W., Driessen, A. J. M. \& Poolman, B. (1987). Primary and secondary transport in Gram-positive bacteria. In Sugar Transport and Metabolism by Gram-Positive Bacteria, pp. 270-294. Edited by J. Reizer \& A. Peterkofsky. Chichester: Ellis Horwood.

Maloney, P. C., Kashket, E. R. \& Wilson, T. H. (1975). Methods for studying transport in bacteria. Metbods Membr Biol 5, 1-49.

Martin, N. L. \& Beveridge, T. J. (1986). Gentamicin interaction with the Pseudomonas aeruginosa cell envelope. Antimicrob Agents Chemother 29, 1079-1087.

Meadow, N. D., Fox, D. K. \& Roseman, S. (1990). The bacterial phosphoenolpyruvate:glycose phosphotransferase system. Annu Rev Biochem 59, 497-542.

Otto, R., Klont, B., ten Brink, B. \& Konings, W. N. (1984). The phosphate potential, adenylate charge and protonmotive force in growing cells of Streptococcus cremoris. Arch Microbiol 139, 338-343.

Peterson, G. L. (1983). Determination of total protein. Methods Enzymol 91, 95-119.

Porter, V. E., Chassey, B. M. \& Holmlund, C. E. (1980). Partial purification and properties of a specific glucokinase from Streptococcus mutans SL-1. Biochim Biophys Acta 611, 289-298.

Postma, P. W. \& Stock, J. B. (1980). Enzymes II of the phosphotransferase system do not catalyze sugar transport in the absence of phosphorylation. $J$ Bacteriol 141, 476-484.

Postma, P. W., Lengeler, J. W. \& Jacobson, G. R. (1993). Phosphoenolpyruvate: carbohydrate phosphotransferase system of bacteria. Microbiol Rev 57, 543-594.
Robillard, G. T. (1987). Functional reconstitution of the purified phosphoenolpyruvate-dependent mannitol specific transport system of Escherichia coli in phospholipid vesicles: coupling between transport and phosphorylation. J Bacteriol 172, 7119-7125.

Roseman, S. (1969). The transport of carbohydrates by a bacterial phosphotransferase system. J Gen Pbysiol 54, 138-184.

Ruijter, G. C. G., van Meurs, G., Verwey, M. A., Postma, P. W. \& van Dam, K. (1992). Analysis of mutations that uncouple transport from phosphorylation in Enzyme $\mathrm{II}^{\mathrm{Gl}}$ of the Escherichia coli phosphoenolpyruvate phosphotransferase system. J Bacteriol 174, 2843-2850.

Russell, J. B. (1990). Low-affinity, high-capacity system of glucose transport in the ruminal bacterium Streptococcus bovis: evidence for a mechanism of facilitated diffusion. Appl Environ Microbiol 56, 3304-3307.

Russell, R. R. B., Aduse-Opoku, J., Sutcliffe, I. C., Tao, L. \& Ferretti, J. J. (1992). A binding protein-dependent transport system in Streptococcus mutans responsible for multiple sugar metabolism. $J$ Biol Chem 267, 4631-4637.

Saier, M., Jr. (1985). Mechanisms and Regulation of Carbobydrate Transport in Bacteria. New York: Academic Press, Inc.

Schöller, M., Klein, J. P., Sommer, P. \& Frank, R. (1983). Protoplast and cytoplasmic membrane preparations from Streptococcus sanguis and Streptococcus mutans. J Gen Microbiol 129, 3271-3279.

Siegel, J. L., Hurst, S. F., Liberman, E. S., Coleman, S. E. \& Bleiweis, A. S. (1981). Mutanolysin-induced spheroplasts of Streptococcus mutans are true protoplasts. Infect Immun 31, 808-815.

Stempek, J. G. \& Ward, R. T. (1964). An improved method for electron microscopy. J Cell Biol 22, 697-701.

Tao, L., Sutcliffe, I. C., Russell, R. R. B. \& Ferretti, J. J. (1993). Transport of sugars, including sucrose, by the $m s m$ transport system of Streptococcus mutans. J Dent Res 267, 4631-4637.

Vadeboncoeur, C. (1984). Structure and properties of the phosphoenolpyruvate: glucose phosphotransferase system of oral streptococci. Can J Microbiol 30, 495-502.

Vadeboncoeur, C., Thibault, L., Neron, S., Halvorson, H. \& Hamilton, I. R. (1987). Effect of growth conditions on levels of components of the phosphoenolpyruvate:sugar phosphotransferase system in Streptococcus mutans and Streptococcus sobrinus grown in continuous culture. J Bacteriol 169, 5686-5691.

Vadeboncoeur, C., St Martin, S., Brochu, D. \& Hamilton, I. R. (1991). Effect of growth rate and $\mathrm{pH}$ on intracellular levels and activities of the components of the phosphoenolpyruvate:sugar phosphotransferase system in Streptococcus mutans Ingbritt. Infect Immun 59, 900-906.

Venable, J. H. \& Coggeshell, R. (1965). A simplified lead citrate stain for use in electron microscopy. $J$ Cell Biol 25, 407-412.

Yamada, T. \& Carlsson, J. (1975). Glucose-6-phosphate dependent pyruvate kinase in Streptococcus mutans. J Bacteriol 124, 562-563.

Yuan, L. C. \& Gulyas, B. J. (1981). An improved method for processing single cells for E.M. utilizing agarose. Anat $\mathrm{Rec}$ 201, 273-281.

Received 4 February 1994; revised 22 April 1994; accepted 16 May 1994. 